\title{
MLL/SEPT5 Fusion Gene
}

National Cancer Institute

\section{Source}

National Cancer Institute. MLL/SEPT5 Fusion Gene. NCI Thesaurus. Code C99333.

A fusion gene that results from a chromosomal translocation $\mathrm{t}(11 ; 22)(\mathrm{q} 23 ; \mathrm{q} 11.2)$ which fuses exon 7 of the MLL gene to exon 3 of the SEPT 5 gene. This rearrang ement is associated with treatment-related acute myeloid leukemia. 